\title{
Enhancement of socio-cultural and intercultural skills of EFL students by means of culture-related extra-curricular events
}

\author{
Yevgeniya B. Novikova - Aleksei Yu. Alipichev - Olga A. Kalugina - \\ Zhanbota B. Esmurzaeva - Stella G. Grigoryeva
}

DOI: 10.18355/XL.2018.11.02.16

\begin{abstract}
This paper considers the enhancement of socio-cultural and intercultural skills of EFL students by means of culture-related extra-curricular events. The purpose of the paper is to ground theoretically and test experimentally the principles for selecting the elements of socio-cultural component which are expedient to be included into the content of foreign languages teaching. Different approaches to develop socio-cultural and intercultural skills in EFL classrooms are analyzed. The effect of culture-related extra-curricular events on socio-cultural and intercultural skills development is presented. The authors highlight didactic characteristics of culture-related extracurricular events that can be taken into account for the enhancement of socio-cultural and intercultural skills. Main characteristics of preparation and carrying out culturerelated extra-curricular events are presented. The example of designing and implementing of culture-related extra-curricular events into EFL teaching was given. The authors come to the conclusion that culture-related extra-curricular events result in the enhancement of the level of language proficiency as well as contribute a lot to bringing up citizens, intellectually, culturally and multi-culturally developed professionals with deep awareness of intercultural values.
\end{abstract}

Key words: socio-cultural and intercultural skills, enhancement, culture-related extracurricular events, intercultural values, didactic characteristics

\section{Introduction}

The teaching of foreign languages is facing new challenges in the modern conditions of emerging the global information space. On the one hand, language teaching aims primarily at developing communications kills in a certain professional sphere, which involves not only considerable methodological efforts to compile terminology bases, but also the development and implementation of special training methods that imply the reproduction of relevant specific features of a certain professional activity. On the other hand, one of the most urgent tasks is the formation of students' abilities to extract useful information from professional texts in a foreign language by means of efficient using appropriate translation strategies, as well as to enable students to organize their own activities in dealing with foreign-language sources, often in a timedeficit environment. Today, it is obvious to many teachers and methodologists that it is not enough for students to have only knowledge and skills in the field of grammar, vocabulary and stylistics to adequately translate, as well as to understand the particulars of a specific industry and its processes. The causes of numerous mistakes in solving study and professional tasks often root from the lack of socio-cultural and intercultural skills, abilities to plan and organize independent study and research activities. Students do perceive knowledge, but they do not always know how to apply it to a specific practical situation working and studying in intercultural environment to solve specific problems, so practical skills of solving real-life problems have to develop spontaneously. In our opinion, a successful study of foreign languages is possible under the following conditions:

- Enhancement of socio-cultural and intercultural skills of EFL students

- Awareness of the practical utility of language knowledge for solving professional and everyday problems 
- Gaining experience of successful communication in a foreign language in situations of study-based communication, including those with foreign students and teachers

- An opportunity to broaden students' outlook by means of a foreign language and with respect to the subjects of their interests.

Organizing culture-related extra-curricular events in universities is aimed at developing future professionals' socio-cultural and intercultural skills and it gives a new opportunity for all interested learners to increase their cultural awareness in the widest sense. Thanks to extra-curricular events held in the English language university students can receive invaluable practice of communication in English which will enhance their chances of employability in future and adaptability to globalizing world. We believe that a socio-cultural component must be included into university English language course and cultural elements must be taught on a regular basis. Events organized in the frames of this approach will stimulate students' interest in cultural phenomena, creativity, self-actualization and improve their communicative competences.

Foreign language communicative competence includes linguistic, pragmatic and socio-cultural components, the latter means ability to interact with people in various socio-cultural environments. Language teachers are unanimous on the ways of developing the first two components, but the question of what socio-cultural competence should include remains open. Though socio-cultural elements can be found in most modern textbooks, there is a need in selected and systematized minimum of cultural elements to be mastered while learning a foreign language.

\section{Review of Literature}

It is clear that culture as a complex and multifaceted concept can hardly be assimilated fully by an individual; therefore, reasonable selection of cultural elements reflecting the culture in all its structural completeness is needed.

The question of what should be included into socio-cultural component has been studied by many researchers, among them R. Hoggart (1990), C. Kramsch (1997), K. Risager (2005), M. Cortazzi, L. Jin (2013, 1999), Barker, (2012), Lorinczova, Tomsik (2017), N. Li, K.V. Pyrkova, T.V. Ryabova (2017), T. Song et al. (2017), J. Birova, D.G. Vasbieva, A.R. Masalimova (2017), A.V. Kazakov, V.G. Zakirova, J. Birova (2017), O.N. Golubkova, A.R. Masalimova, J. Birova (2017), S. Wang et al. (2018) and others. Some maintain that culture as a very complicated and multilateral phenomenon cannot be mastered by learners in full volume. So, the task of the highest priority is ground theoretically and test experimentally the principles for selecting elements of culture which are expedient to be included into the content of foreign languages teaching.

For selection of such cultural elements we consider appropriate to use a threedimensional model of "the cultural space" (Karmin, 2001), which includes three subsystems: technological culture, spiritual culture, social culture, and, accordingly, we select elements of culture for formation of the cultural personality in 1) the sphere of material production; 2) the spiritual and moral sphere; 3) social relations.

N.V. Saienko (2012) offers the following generalized list of subsystems and elements of culture which should be mastered by students: the sphere of material production including knowledge of science, technology, law, economy, ecology, etc.; the spiritual sphere including everyday activities (as a set of customs, rituals, forms of behavior), philosophy, psychology, arts and literature, religion, ethics, cultural studies, etc.; the sphere of social relations including political science, sociology, history, language, communication (including intercultural) and others.

Different approaches are proposed to develop socio-cultural and intercultural skills in EFL classrooms. Majority of scientists consider an intercultural approach as a means of enhancement of socio-cultural and intercultural skills of EFL students. "In the

XLinguae, Volume 11, Issue 2, April 2018, ISSN 1337-8384, eISSN 2453-711X 
intercultural approach, the goal of FL teaching is 'to accommodate the two worlds in the learner's mind..., to sharpen the learners' awareness of similarities and differences and help them to come to terms and deal with divergent experiences" (Neuner, 1997). H. Chia-Lin (2008) suggests that adapting an intercultural approach in FL learning integrates learners' local content into communicative activities to both improve learners' motivation in learning the language and also train learners as an intercultural speaker or an ethnographic learner.

Successful international communication is reasonable enough to introduce the intercultural approach in EFL classrooms (Chlopek, 2008). I. Salamatina and Zh. Strebkova (2016) investigated the use of socio-cultural approach in developing social and cultural awareness in FLT. The essence of socio-cultural approach is in teaching foreign languages as a means of international communication. Socio-cultural education which is driven by FLT is targeted at of special type of world perception by the students. It aims at creating an individual who is receptive to the history of humanity and his own nation, building in him cultural and moral awareness on the global scale. It also focuses on the development of communication skills and unraveling the students spiritual potential, teaching about ethically accepted and legally justifiable forms of social self-expression and discussion.

Although there were numerous studies regarding the development of intercultural communicative competence which includes socio-cultural and intercultural skills of EFL students within the English language course (Young et al. 2012; Cetinavci, 2012; Galante, 2015; Storey, 1993), studies concerning the enhancement of socio-cultural and intercultural skills of EFL students by means of culture-related extra-curricular events are rather limited.

Doing research on the role of extracurricular activities in foreign language learning in University settings A. Reva (2012) examined extracurricular activities in North America, Canada and Russia, and revealed the fact that in general language-related ECA affects positively all the aspects of students' language acquisition. However, there are some problems with organizing ECA, the: uncertainty about who should be responsible for this part of language instruction, and lack of spare time due to the busy schedules of both students and instructors in all countries.

In our study we will make attempts to present the list of culture-related extracurricular events to enhance socio-cultural and intercultural skills of EFL students and work out methodological aspects of culture-related extra-curricular events' management based on intercultural approach and socio-cultural approach.

\section{Materials and Methods \\ 3.1 Research methods}

The following methods have been used in our research: survey data analysis, evaluation of educational outcomes, systematization and categorization of facts and concepts.

A wide range of educational organizations (non-linguistic higher schools): Financial University under the Government of the Russian Federation, Kharkiv National Automobile and Highway University, Omsk State Agrarian University named after P.A. Stolypin, Moscow Agricultural Academy named after K.A. Timiryazev, Moscow Aviation Institute (National Research University) was involved into the study. It allowed more broadly and objectively to assess the enhancement of socio-cultural and intercultural skills of EFL students by means of culture-related extra-curricular events.

\subsection{Research Stages}

The research was conducted in three stages.

The first stage involved: studying previous research; defining the subject matter, scope and purpose of the research; developing a hypothesis; formulating research objectives; defining methods appropriate to the purpose and objectives of the study; identifying research facilities. 
In the second stage we conducted the survey data analysis to gain an insight into enhancement of socio-cultural and intercultural skills of EFL students by means of culture-related extra-curricular events. We selected socio-cultural components and culture-related extra-curricular events and integrated them into university English language course.

The third stage included investigation, development and implementation of special culture-related extra-curricular events that imply the reproduction of relevant specific features of a certain professional activity and enhance socio-cultural and intercultural skills of EFL students; systematization and analysis of the results obtained; drawing conclusions.

\section{Results and Discussion}

The purpose of this research paper was enhancement of socio-cultural and intercultural skills of EFL students by means of culture-related extra-curricular events. To carry out the research on enhancement of socio-cultural and intercultural skills of EFL students by means of culture-related extra-curricular events, three research questions were formulated:

1. What innovative elements enhancing socio-cultural skills in language teaching should be introduced?

2. What didactic characteristics can be taken into account for the enhancement of socio-cultural skills in EFL teaching?

3. What are the main stages of designing and implementing of culture-related extracurricular events?

\subsection{Involvement of students in culture-related extra-curricular events}

One of the objectives of university extra-curricular events is intense involvement of students in various cultural practices in the English language. We attempt to carry out special events that are supposed to motivate students to learn various aspects of English: students participate in contests of essays and round tables covering topical social, economic, political, psychological, ethic issues; brain games that test their knowledge of culture and stimulate to learn English in all its variety.

Our universities have been introducing certain innovative elements in language teaching enhancing socio-cultural skills in various forms. Contests, intellectual games, quizzes, debates, round-tables, annual publication of students' research works, artistic initiatives, workshops and conferences for students are organized at the interuniversity and international levels.

Our aim is to create, disseminate and mainstream new approaches to the use of foreign language study for developing university students' spirituality, citizenship and multi-cultural literacy, establishing socio-cultural relations between students and teachers.

Involving students in a variety of culture-related events in foreign language stimulates their cultural awareness, civic commitments and artistic initiative as well as develops their linguistic skills. We try to achieve this by organizing numerous culture-related events: contests of essays, intellectual games "What? Where? When?", "brain-rings", quizzes, activities stimulating civic commitments among young people (debates, forums, round-tables); organization of conferences related to the best practices in language learning; organization of workshops of excellence in to disseminate experience received in the process of project implementation and its results; issuing the annual collection of students' research works and essays.

During the experiment, general didactic characteristics of culture-related events for the development of socio-cultural and intercultural skills were defined (see table 1).

Table 1: Didactic characteristics of culture-related events 


\begin{tabular}{|l|l|}
\hline Culture-related events & Didactic characteristics \\
\hline Contests of essays & $\begin{array}{l}\text { stimulate students' abilities to state their attitudes, } \\
\text { support their ideas and prove their opinions }\end{array}$ \\
\hline Brain-games & $\begin{array}{l}\text { reveal the level of participants' erudition in cultural } \\
\text { issues, motivate to enhance it, sharpen their minds, } \\
\text { involve in competition, encourage winning }\end{array}$ \\
\hline $\begin{array}{l}\text { Activities stimulating } \\
\text { civic commitments } \\
\text { among young people }\end{array}$ & $\begin{array}{l}\text { provide discussions on various socio-political topics } \\
\text { when each participant's opinion and any opposing view } \\
\text { will be respected }\end{array}$ \\
\hline $\begin{array}{l}\text { The students' } \\
\text { conferences }\end{array}$ & $\begin{array}{l}\text { disseminate the results of students' research works and } \\
\text { projects. }\end{array}$ \\
\hline Workshops & $\begin{array}{l}\text { share best practices, help teachers reflect on their } \\
\text { professional achievements and skills, provide an } \\
\text { opportunity to assemble and organize their evidence for } \\
\text { appraisal and revalidation; encourage to practice and } \\
\text { learn new skills in teaching foreign languages, offer } \\
\text { new ways in which teachers can reflect on and } \\
\text { articulate their professional values as a teacher or } \\
\text { scholar in language education. }\end{array}$ \\
\hline
\end{tabular}

\subsection{Main characteristics of preparation and carrying outculture-related extra- curricular events for socio-cultural and intercultural skills enhancement}

As modern experience of foreign languages departments of various universities (including non-linguistic ones) shows, a wide range of inter-university (including international) events and activities are very effective means of forming motivation for studying foreign languages through the development of intercultural and strategic competences in students. The main advantages of such activities for students are the following:

- an opportunity of distant (including real-time) participation without the need to organize trips to other cities and countries, which require considerable funding

- a possibility to see the best solutions for the same study problems (cases, or tasks) and analyze the experience of other participants

- an opportunity of obtaining recognition from outside experts, professionals and the student community, and thereby gaining confidence in their ability to work with a foreign language and form their "language portfolio".

Still explicit are the advantages for the academic staff of foreign language development (FLD):

- methodological and research experience exchange

- making professional contacts and extending professional networks with domestic and international colleagues

- capacity building of their FLD by approving and implementing original and efficient methods in the field of general and professional language teaching.

Financial University under the Government of the Russian Federation, Kharkiv National Automobile and Highway University, Omsk State Agrarian University named after P.A. Stolypin, Moscow Agricultural Academy named after K.A. Timiryazev, Moscow Aviation Institute (National Research University) have considerable and time-tested experience of cooperation with many universities in Russia, CIS and European countries. Undergraduate and graduate students, as well as postgraduates participate in various inter-university and international competitions, the main types of which include:

- contests of essays and other types of academic writing genres

- contests for the best translation of professional, technical, mass media materials and poetry 
- on-line dictation in a foreign language ("Total Dictation")

- contests of video clips and presentations in a foreign language (digital story telling)

- scientific conferences held in the distant (real-time, or on-line) mode.

Here we consider the main characteristics of preparation and carrying out of an international contest for the best translation in a real-time on-line mode. The contest has been organized for a number of years by the Department of Foreign Languages of Moscow Agricultural Academy named after K.A. Timiryazev in cooperation with Financial University under the Government of the Russian Federation, Kharkiv National Automobile and Highway University, Omsk State Agrarian University named after P.A. Stolypin, Moscow Aviation Institute (National Research University) with the purpose to enhance socio-cultural and intercultural skills of EFL students, assessing the participants' level of proficiency in the field of analyzing foreign language texts and performing their adequate translation, as well as evaluating the formation of professional pragmatic, strategic and translational competences.

The contest originated as a local event in 1990s, but later on the organizers decided to extend the borders and attract the maximum possible number of participants by making the contest international and arranging it in an on-line mode.

Here we will try to clearly identify the main stages of designing and implementing the translation contest. First of all, we can distinguish two separated but still interconnected aspects - organizational and methodical ones.

Organizational actions include sending information letters to partner departments describing the contest procedure. At the first stage (the qualifying round), the Organizing Committee sends first-stage texts to the partner departments for the preliminary selection, students (within a specific quota for each partner institution) do their translations in their home universities in an appropriate format (either in person in a classroom or at home in an on-line form), only those who get 1-2-3 prizes proceed to the second stage. Partner departments can add additional creative tasks at their own discretion. Participants of the first stage (qualifying round), who do not win prizes, shall get certificates. Winners shall get diplomas of the first stage and shall be invited to the second stage, which is held online. The first (preliminary selection) local stage gives an opportunity to attract more participants (and, accordingly, prizewinners), on the other hand, basing on the analysis results of their mistakes made at the first stage, students may get the opportunity to analyze their mistakes and prepare in a better way, and the quality of the second stage outcomes can be increased significantly. Then the exact date and time of the online stage is reported, when contest tasks are sent to a specific general mailbox created for the contest with a password known to all participants. On the day of the contest, the tasks sent to participants must be done within the strictly specified time period (it can vary depending on the volume of the translated texts and additional tasks). Completed tasks are sent by participants to the address of the Organizing Committee of the contest; while only the members of the organizing committee are authorized to get access to it (this ensures the confidentiality of information). Files with contest tasks are assigned a specific code (for example, a numerical coding of the date of birth of a participant). Responsible persons appointed by the partner departments, produce a separate file with registration data of participants and their personal codes. Thus, in the process of checking the contest works, their authors remain unknown, thereby ensuring the impartiality of the evaluation and increasing the objectivity of results.

The methodological aspect includes the selection of materials for translation and the elaboration of additional creative tasks. In the first years of the contest we considered the specific sphere of the future professional activity of our students as the determining factor when choosing the contest texts. In particular, for students of technical and technological universities we offered the following thematic areas: "Main Trends of Economic Development", "Mechanization of Farm / Industrial

XLinguae, Volume 11, Issue 2, April 2018, ISSN 1337-8384, eISSN 2453-711X 
Production and Current Features of Modern Technology", "Electrification and Computerization of Industry". However, later on, due to the expansion of the network of participating universities, including the humanities ones, as well as technical universities with their narrow training profiles, it was decided to offer some general problems for all students. Accordingly, the contest topics in different years covered the following areas: "General State of Modern Industry on the Path to Sustainable Development", "Future of Science in Modern Society", "Trajectories of Professional Development of Specialists", "Challenges and Prospects of Modern Education", "Human Resource Training for Modern Enterprises".

In selecting text material to be translated, the question arises about the selection principles, or criteria, to be guided. In our opinion, the following principles can be the leading ones (Ozerova, 2000):

- cognitive simplicity

- authenticity of the information sources used

- typicality for the considered subject area

- professional-pragmatic representativeness of speech resources

- coverage of the range of tasks to be solved

- respect for the specific features of native and foreign language when comparing speech and grammatical models

- effectiveness as a means of motivation for the forthcoming professional activity.

In our opinion, it is inappropriate to use the texts for reading and discussion from specialized manuals or foreign textbooks, as well as modern and classical fiction. At the same time, texts with a rigid preset structure containing special clichés and professionalisms are not effective enough in terms of their ability to reflect the variety of translation methods, implement pre-translational text analysis, and choose the translation register and style. This range includes the following types of texts: scientific and technical documentation (patents, abstracts, monographs), technical and technological documentation (standards, technical descriptions for equipment, instructions for installation and operation, repair manuals, feasibility studies, etc.); legal and organizational-and-economic documentation and official documents (contracts, certificates, safety regulations, commercial proposals, contracts, etc.)

Priority, in our opinion, should be given to analytical and scientific-popular texts (analytical articles, information reviews, etc.), as well as promotional materials, announcements, press releases, blog materials, in other words - mass media texts that reflect the general actual problems of our time.

Such texts should reflect all grammatical and lexical phenomena typical for styles and genres of popular science and professionally oriented communication, as well as the most frequent terms. The selected texts should be analyzed from linguistic and extralinguistic positions - to determine the volume (in printed characters), the logical and composition structure, and a possibility of attracting relevant illustrative material.

Organizationally, the contest is an independent work of students in translating texts of up to 3000 characters within a specified time period using only a dictionary.

The structure of the contest task is as follows:

- to make the written translation of the proposed text

- to suggest options for translating the text title for three target audiences

a) readers of the popular science press, b) the academic community, c) the student audience

- to render the main idea of the proposed text most fully in one sentence in a foreign language

- to write a motivated "answer" to the author of the text, indicating the strengths and weaknesses of his position and indicating one's own point of view.

The evaluation of the performed work is carried out with account of the criteria for the effectiveness of professional activity, which are its quality, productivity and reliability 
(Shadrikov, 1982). With regard to translation, these criteria reflect, in our opinion, respectively:

- the translation correctness - the acquisition and proper useof language systemstructural features and norms

- the translation fluency - the quality of a foreign language mastery, the ease of communication

- the translation adequacy and optimality - the ability to choose linguistic means and transform information without distortion, basing on pragmatic characteristics of the situation and professional tasks to be solved.

Table 2:Criteria for evaluating competitive translation

\begin{tabular}{|l|l|}
\hline Criteria & \multicolumn{1}{|c|}{ Error Types } \\
\hline Quality & Lexical errors (incorrect translation of terms and set expressions) \\
\cline { 2 - 2 } & $\begin{array}{l}\text { Grammatical errors (mistakes in translating the tense and voice marks, } \\
\text { collateral, subjunctive, conditional turns, errors in choosing the meaning of } \\
\text { polysemic words) }\end{array}$ \\
\cline { 2 - 2 } & $\begin{array}{l}\text { Stylistic errors (inconsistency with the required functional style, non- } \\
\text { naturalness of the final text) }\end{array}$ \\
\hline Reliability & $\begin{array}{l}\text { Violation of logical, cause-and-effect relationships, distortion of meaning, } \\
\text { omission of factual information }\end{array}$ \\
\hline Productivity & $\begin{array}{l}\text { The volume of the translation made within a specified time period is } \\
\text { estimated (in percentage terms) }\end{array}$ \\
\hline
\end{tabular}

Based on the assessment results, a "negative rating" can be calculated and expressed in "penalty" points, accrued for each error committed of a specific type, and the smallest negative rating allows identifying the winners in each nomination. Control and evaluation of the contest tasks according to the adopted criteria is carried out by the Organizing Committee of the contest with the involvement of experts (teachers of special departments of Russian Timiryazev State Agrarian University). In accordance with the contest tasks and the working languages, the winners are identified by the main language categories. In addition, the winners are awarded with diplomas in additional nominations for certain skills. The list of nominations is determined, in particular, by qualitatively fulfilled additional tasks of the contest.

Here are the grounds for awarding additional nominations:

- Optimal translation solutions of individual sentences or constructions

- Non-standard distinctive translation variants of the text title (for different target audiences)

- The most complete and concise presentation of the main idea of the text in one sentence in a foreign language

In the University's website, the contest results are freely available: the names of the winners in each nomination, the best works as well as statistical information (the total number and geography of participants, the percentage of "rejected" works and the degree of originality).

In 2015, for the first time, a survey was conducted among the partner departments on their evaluation of the very idea of the contest, as well as the quality of its preparation and implementation.

The main ideas to improve the contest included:

- increasing and diversifying tasks with increasing the preparation time

- organizing communication of the contest participants (groups in social networks, the contest site) and remote (webinar or videoconference between the winners and organizers)

- offering translation from Russian into a foreign language (as a separate task) 
- selecting text material, proceeding from the principles of universality, functionality, accessibility, and emphasizing the importance of selecting texts without specific thematic reference

- publishing first-prize translation works, which can allow participants and their language supervisors analyze and modify the translation of the text and discuss possible interpreting solutions

- finalizing the technical issues of sending the contest tasks, sending out the algorithm to the participants in advance (or provide an alternate option).

The wide use of such contest-like activities in the study process allow students to learn to use a foreign language as a means of professionally oriented communication and solving specific practical socio-cultural problems. Experience shows that students demonstrate keen interest in such activities and are eager to expand their language abilities and skills and improve their translation skills.

\section{Conclusion}

Thus the extra-curricular events mentioned above, create new opportunities in teaching and learning English. Thanks to extra-curricular events held in the foreign language students from our universities receive good practice of communication in the foreign language which will enhance their chances at their future workplaces all over the world. Moreover, foreign languages and socio-cultural competences have crucial importance for students' ability to take part in future national and international projects involving mobility or traineeships, and young people who have developed relevant skills will be much more adaptable to the globalizing world compared to others who lack similar experiences.

The deliverables of culture-related extra-curricular events, besides enhancing the level of language proficiency, can contribute a lot to bringing up citizens, intellectually, culturally and multi-culturally developed professionals with deep awareness of intercultural values. Our investigations into this area are still ongoing. This research has thrown up many questions in need of further examination of enhancement of socio-cultural and intercultural skills of EFL students by means of culture-related extra-curricular events.

\section{Acknowledgements}

1. The work is performed according to the Program of Development of Federal State-Funded Educational Institution of Higher Education "Financial University under the Government of the Russian Federation" for 2020.

2. The work is performed according to the Russian Government Program of Competitive Growth of Kazan Federal University.

\section{Bibliographic references}

BARKER, C. 2012. Cultural Studies. Theory and Practice. London: SAGE. ISBN-13 978-0857024800.

BIROVA, J. - VASBIEVA, D.G. - MASALIMOVA, A.R. 2017. Communication in French foreign language learning by implementing the aspects of interculturality. In: Communications - Scientific Letters of the University of Zilina, vol.19, n. 4, pp. 95104. ISSN:1335-4205.

CETINAVCI, U. 2012. Intercultural communicative competence in ELT. In: Procedia - Social and Behavioral Sciences, vol. 46, pp. 3445 - 3449. ISSN: 1877-0428

CHIA-LIN, H. 2008. Language and Culture in Foreign Language Teaching. Newcastle University. Available online: http://www.leeds.ac.uk/educol/documents/178899.pdf

CHLOPEK, Z. 2008 The Intercultural Approach to EFL Teaching and Learning. Available online: https://americanenglish.state.gov/files/ae/resource_files/08-46-4c.pdf 
CORTAZZI, M. - JIN, L. 1999. Cultural mirrors. Culture in Second Language Teaching and Learning. Cambridge: Cambridge University Press. ISBN-13 9780521644907

CORTAZZI, M. - JIN, L. 2013. Introduction: Researching cultures of learning. Macmillan: Macmillan Publishers Limited. ISBN 978-1-137-29634-4.

GALANTE, A. 2015. Intercultural Communicative Competence in English Language Teaching: Towards Validation of Student Identity. In: BELT Brazilian English Language Teaching Gernal. Porto Alegre, vol. 6, n. 1, pp. 29-39. ISSN 2178-3640.

GOLUBKOVA, O.N. - MASALIMOVA, A.R. - BIROVA, J. 2017. The Development of Sociocultural Competence in Future Translators Via the Methodology of Culture-Oriented Interpretation of English Language Fictional Texts. In: Man In India, vol. 97, n. 14, pp. 73-83. ISSN:0025-1569

HOGGART, R. 1990. The Uses of Literacy. Harmondsworth, Penguin; New Ed edition. ISBN-10 0140124772.

KARMIN, A.S. 2001. Culturology. St.Petersburg: Lan. ISBN 5-8114-0249-X

KAZAKOV, A.V. - ZAKIROVA, V.G. - BIROVA, J. 2017. Modeling the Process of Forming Social and Cultural Competence among Students of Linguistics Faculty. In: Man In India, vol. 97, n. 14, pp. 291-305. ISSN: 0025-1569

KRAMSCH, C. 1997. The cultural component of language teaching. In: British Studies Now, n. 8, pp. 4-7.ISSN 0966-369X

LI, N. - PYRKOVA, K.V. - RYABOVA, T.V. 2017. Teaching Communication Skills and Decision-Making to University Students. In: EURASIA Journal of Mathematics, Science and Technology Education, vol. 13, n. 8, pp. 4715-4723. ISSN: $13058215,13058223$.

LORINCZOVA, E. - TOMSIK, R. 2017. Comparison of social skills between intact pupils and pupils with special educational needs in mainstream primary schools. In: Slavonic pedagogical studies journal, vol. 6, n. 1, pp. 12 - 21. ISSN 1339-8660 10.18355 .

NEUNER, G. 1997. The role of Sociocultural Competence in Foreign Language Teaching and Learning. In: Language Teaching, vol. 29, n.4, pp. 234-239. ISSN 0261-4448.

OZEROVA, M.V. 2000. Soderzhaniye professional'no oriyentirovannogo obucheniya inostrannomu yazyku v neyazykovom vuze. In: Collection of scientific works. Professional communication as the goal of teaching foreign languages in a nonlinguistic university, issue 454, pp. 23-32. Moscow: MGLU.ISSN 1993-4750. 06.

REVA, A. 2012. The Role of Extracurricular Activities in Foreign Language Learning in University Settings: A Thesis Submitted to the College of Graduate Studies and Research In Partial Fulfilment of the Requirements For the Degree of Master of Arts In the Department of Languages and Linguistics University of Saskatchewan Saskatoon. Available online: https://ecommons.usask.ca/bitstream/handle/10388/ETD-2012-06-507/REVA-THESIS.pdf?sequence=3

RISAGER, K. 2005. Languaculture as a Key Concept in Language and Culture Teaching. Denmark: Roskilde Universitet.ISBN: 978-87-616-2034-7.

SAIENKO, N.V. 2012. Theoretical and methodical principles of culturological training of future engineers. In: monograph. Kharkiv: HNADU.ISBN 978-966-303473-7

SALAMATINA, I - STREBKOVA, ZH. 2016. Developing social and cultural awareness in Foreign language teaching. Available online: https://cyberleninka.ru/article/v/developing-social-and-cultural-awareness-in-foreignlanguage-teaching

SHADRIKOV, V.D. 1982. The problem of the systemogenesis of professional activity. Moscow: Nauka. ISBN 5-17-039718-6

XLinguae, Volume 11, Issue 2, April 2018, ISSN 1337-8384, eISSN 2453-711X 
SONG, T. - USTIN, P.N. - POPOV, L.M. - MUDARISOV, M.M. 2017. The Educational Technology of Ethical Development for Students. In: EURASIA Journal of Mathematics, Science and Technology Education, vo. 13, n. 6, pp. 2095-2110. ISSN: 13058215, 13058223.

STOREY, J. 1993. An Introductory Guide to Cultural theory and Popular Culture. Athens : University of Georgia Press, 1993 ISBN. 238 p. 0820315907

TSVETKOVA, M.I. 2017, The Speed Reading is in Disrepute: Advantages of Slow Reading for the Information Equilibrium. European Journal of Contemporary Education, vol. 6, n. 3, pp. 593-603. DOI: 10.13187/ejced.2017.3.593

YOUNG, T.J. - SERCOMBE, P.G. - SACHDEV, I.N. - SCHARTNER, A. 2012. Success factors for international postgraduate students' adjustment: exploring the roles of intercultural competence, language proficiency, social contact and social support. In: European Journal of Higher Education, vol. 3, n.2, pp. 151-171. ISSN: 2519-1764. WANG, S. - GORBUNOVA, N.V. - MASALIMOVA, A.R. - BIROVA, J. SERGEEVA, M.G. 2018. Formation of Academic Mobility of Future Foreign Language Teachers by Means of Media Education Technologies. EURASIA Journal of Mathematics, Science and Technology Education, vol. 14, n. 3, pp. 959-976. ISSN: $13058215,13058223$.

Words: 5333

Characters: 38657 (21,48 standard pages)

Assoc. Prof. Yevgeniya B. Novikova, PhD

Department of Foreign Languages

Kharkiv National Automobile and Highway University

25 Yaroslav Mudry Str.

61002 Kharkiv

Ukraine

vasilyok@ukr.net

Assoc. Prof. Aleksei Yu. Alipichev, PhD

Foreign Languages Department

Russian State Agrarian University - Moscow Timiryazev Agricultural Academy

Timiryazevskaya Str., 49

127550 Moscow

Russia

al_new2003@mail.ru

Assoc. Prof. Olga A. Kalugina

Department of Foreign Languages

Financial University under the Government of the Russian Federation

Leningradsky prospect 49

125993 Moscow

Russia

kaluginaruc@mail.ru

Assoc. Prof. Zhanbota B. Esmurzaeva, PhD

Department of Foreign Languages

Omsk State Agrarian University n.a. P.A. Stolypin

1 Institutskaya square

644008 Omsk

Russia

yesmurzaeva@mail.ru 
Prof. Stella G. Grigoryeva, Dr. of Education

Institute of Psychology and Education

Kazan (Volga region) Federal University

18 Kremlyovskaya Str.

420008 Kazan

Russia

ste-grigoreva@yandex.ru 